Portland State University

PDXScholar

Engineering and Technology Management

Faculty Publications and Presentations

$9-1-2016$

\title{
Impacts to Productivity in Metal Stud Framing, and the Hanging and Finishing of Gypsum Drywall
}

Gerald H. Williams Jr.

Construction Research, LLC

Timothy R. Anderson

Portland State University, tim.anderson@pdx.edu

Follow this and additional works at: https://pdxscholar.library.pdx.edu/etm_fac

Part of the Operations Research, Systems Engineering and Industrial Engineering Commons Let us know how access to this document benefits you.

\section{Citation Details}

Williams, Gerald H. Jr. and Anderson, Timothy R., "Impacts to Productivity in Metal Stud Framing, and the Hanging and Finishing of Gypsum Drywall" (2016). Engineering and Technology Management Faculty Publications and Presentations. 110.

https://pdxscholar.library.pdx.edu/etm_fac/110

This Article is brought to you for free and open access. It has been accepted for inclusion in Engineering and Technology Management Faculty Publications and Presentations by an authorized administrator of PDXScholar. Please contact us if we can make this document more accessible: pdxscholar@pdx.edu. 


\title{
Impacts to Productivity in Metal Stud Framing, and the Hanging and Finishing of Gypsum Drywall
}

\author{
Gerald H. Williams, Jr. ${ }^{1}$, Timothy R. Anderson ${ }^{2}$ \\ ${ }^{1}$ Construction Research, LLC, United States \\ ${ }^{2}$ Dept. of Engineering and Technology Management, Portland State University , United States
}

\begin{abstract}
Stud Framing, Drywall, and Tape and Finishing trade-work is a major component of every building project. Labor productivity is the largest single variable affecting of the Framing and Drywall contractors' cost of performance. In spite of these facts, no major study of labor productivity in this major construction trade has previously been done. This study was undertaken to fill this gap in the literature; specifically to investigate external impacts to labor productivity in this construction sector. The study measured the impact of thirtyeight (38) variables on 226 separate projects. The study found that poor quality design documents, unexpected labor congestion, fragmentation, and overtime and added shift work negatively impacted labor productivity.
\end{abstract}

\section{INTRODUCTION}

Construction is one of the largest sectors of the U.S. economy, directly employing five percent of all U.S. workers. Labor is a major component of construction project costs. In the Metal Stud, Drywall, Taping and Finishing trades, direct labor accounts for sixty to seventy percent $(60 \%-70 \%)^{1}$ of the total cost of production. As a consequence, labor productivity is a principal concern to these trade contractors.

The field of labor productivity investigations in the construction sector is relatively mature. Of the more than 2500 published citations $^{2}$ in our database related to productivity, scheduleing, estimating and so on in the construction industry, only a handful (fewer than 150) have been published since 2010, and severeal of those were case studies of a few projects [58] [33, 40], many others were on construction claims [16, 32, 69], impact of changes [26, 62] and some broader construction industry wide studies [1, 5-7, $17,20,52,55]$ but none were studies examining labor productivity impact is an entire trade or sector of the construction industry except an update on the electrical trades by Hanna [24]. Past industry studies have only examined the productivity impacts for mechanical and electrical trades. And as noted, no such study has been completed for the drywall industry, in a recent paper by Kovars [37], the only industry studied examined were the Mechanical Contractors Association of America (MCAA) [44] and studies by National Electrical Contractors Association (NECA) [48, 51, 50], now updated by the Electrical Contracting Foundation

\footnotetext{
${ }^{1}$ Based on a random sample of projects obtained for this study, labor does not include equipment, materials or overhead supervision such as project management.

${ }^{2}$ Some citations in our database are to important legal holdings affecting the construction industry.
}

[23]. To fill this gap in the literature, in 2006, the Northwest Wall and Ceiling Bureau (NWCB) and the Northern California Drywall Contractors Association (NCDCA) embarked on a project to study the impacts on labor productivity for their members in the metal stud, drywall, and taping and finishing trades.

In the construction industry, labor productivity is a function of three primary functional variables: the environment in which the work is to be executed, the manner in which the construction contractor is allowed to execute the work, and the internal capabilities of the construction firm. Within these functional variables there are several specific factors commonly regarded as having a significant potential impact on construction labor productivity [30], [60]. These factors have been studied extensively and can be broken into two broad groups: internal and external (sometimes referred to as controllable and uncontrollable). The internal factors can be further reduced to two types: quality of the estimate, and quality of the project team. The external factors can be reduced to four types: those which represent a fundamental change in the natural physical environment (such as weather); those which result in congestion of the work (material, equipment and personnel); those which result in fragmentation of the work (disruptions); and those related to external project management (owner or general contractor). This investigation is focused solely on the external factors, which are not controllable by the trade contractor.

Within these broad factors, there are numerous variables that describe, or are a function of, the factors. Often, one factor or variable in and of itself will not be terribly detrimental to a project's performance. However, a ripple effect is associated with almost every factor and this effect is worsened by each individual occurrence of productivity loss factors.

For the purposes of this study, we will use a commonly accepted definition of productivity loss: "the decline in labor efficiency due to specific causes from the level which could have been achieved except for the cause(s) under examination" [47].

\section{LITERATURE REVIEW}

There have been a number of studies on labor productivity in the construction industry by major trade organizations such as NECA and MCAA, academic institutions such as the Construction Industry Institute (CII) [8, 9, 11, 12], and government agencies such as the U.S. Army Corps of Engineers [67] and the Department of Labor [14] dating back 
to the 1960's. Additionally, there have been numerous studies published in major academic journals. A compilation of these can be found in Impacts to Labor Productivity in Steel Framing and the Installation and Finishing of Gypsum Wallboard [68] and Estimating Lost Labor Productivity in Construction Claims [45]. This study measured the productivity impact of 38 separate variables derived from the prior literature and an independent panel of senior industry executives. These impact variables included: Management, Scheduling and Acceleration, Changes in the Work, and Weather.

\section{A. MANAGMENT}

Productivity in general has been studied for many years, beginning with social scientists' study of management and motivation. While theoretical and explanatory organizational behavior studies abound, very few have been applied to the construction industry. Motivation and morale play a major role in the productivity of workers on any construction project. Management is responsible for motivating the crew, carrying out the plan, and solving an array of on-site issues. Motivation in the construction industry has been studied by several other researchers most notably William Maloney [41], [42], [43].

\section{B. SCHEDULING \& ACCELERATION}

A large portion of the productivity loss in construction projects is the result of schedule-related problems stemming from acceleration of the work. Acceleration that causes the contractor to add labor forces to the job has been shown to result in lower levels of labor productivity through overmanning of crews, trade stacking, crowding of workers and materials, and dilution of supervision.

\section{Congestion:}

Congestion of labor and materials can result from trade stacking, crowding, or other crew over-manning [25]. Trade stacking is another way to accelerate a project and is the process of overlapping trade work in the field which results in a greater density of workers performing different types of work in the same workspace.

The USACOE Modification Impact Evaluation Guide [66], projected that crowding, calculated as the percentage greater than the scheduled manpower, will result in labor productivity losses as high as $18 \%$ (based on a maximum of $35 \%$ Crowding). Other prominent publications that deal with crowding and trade stacking include: [57], [56], [36], and [61].

\section{Overtime:}

Overtime work can create direct and indirect productivity losses. Direct reduction in productivity is a product of the overtime itself - generally fatigue. Overtime has been shown to result in a direct reduction in labor productivity when required over a number of weeks. Furthermore, overtime's negative effects on productivity are aggravated depending on the number of overtime hours per day and the duration over time [27]. The law of diminishing returns eventually takes effect at which point added overtime actually decreases production rates ${ }^{3}$. Various studies have predicted a loss in productivity due to overtime as high as 40\% [49], [63], [64]. The productivity effects resulting from overtime work were first studied by the Bureau of Labor Statistics and published in its 1947 Bulletin No. 917 [14].

\section{Dilution of supervision:}

An increase in field trade labor can result in a dilution of supervision, meaning that the supervisor must manage more workers, resulting in less direct time supervising and directing each individual. The consequence of this dilution is worker inefficiency. It stands to reason that increasing the number of workers supervised will inevitably result in less direct contract and poorer communication between worker and supervisor, thus degrading the quality of the supervision received [65].

\section{Disruption and Fragmentation:}

Disruption and subsequent fragmentation of the work is distinctly different from congestion. Disruptions nearly always result in work fragmentation. Loss due to fragmentation has historically been dealt with by considering the cost of remobilizing to the site of the disruption [4].

However, "lost learning" can also be considered for more reliable modeling. "Lost learning" results from repeated learning curves due to the stopping and starting [15] [53] [34].

In its most basic form, a learning curve is present when work is performed repeatedly, and as a result the worker becomes more productive doing the task. Much has been written about learning curves, dating back to the 1930's [3] [15]. As any production cycle increases in duration, and the number of units produced in a repetitive process increases, the cost, or man-hours, to produce the quantity declines by a constant, fixed percentage of the previous cumulative average units. This constant percentage is often referred to as the experience factor. In the construction application, the learning curve is the inverse of the crew production cycle discussed above [19].

\section{Ramp-up/Ramp-Down:}

In order for a contractor to move from a normally sized crew to an overmanned crew, the workforce must experience a "ramp-up" or transitional phase, where workers are rapidly added to the workforce. During this phase a contractor is likely to suffer losses in productivity similar to those resulting from learning curve and other workforce

\footnotetext{
${ }^{3}$ For example if a crew is worked 7 days a week 12 hours a day for $8-1 / 2$ weeks, a NECA (1989) study predicts the workers productivity will be only $45 \%$ of normal. This means that even though the crew works 84 hours in a week, it only earns $45 \%$, or 37.5 hours of production.
} 


\section{Proceedings of PICMET '16: Technology Management for Social Innovation}

inefficiencies. Further, "ramp-up" phases often result in dilution of supervision because it is difficult for contractors to add supervisors as quickly as workers. Additionally, the workers added may not be of the same caliber or experience as the firm's ordinary workforce, resulting in a higher than expected rate of turn-over.

There has been little research on the loss of productivity during the ramp-up or ramp-down transition phases. Most research, as cited above, has focused on the steady-state condition after the ramp-up (the "overmanned" crew inefficiencies). In one unpublished study prepared to assist in resolving a dispute, the analysts found that every man-hour of labor resource (manpower) added to the job during the "ramp-up" phase, resulted in 0.85 man-hours of production. In other words, during the ramp-up phase, when workers were rapidly ${ }^{4}$ added to the payroll, the average labor productivity suffered a $15 \%$ loss. Ramping down the workforce rapidly as the project comes to an abrupt end also has not been studied in any depth. Estimates of this possible productivity impact by construction supervisors vary greatly from little at all (because they terminate workers they think may be slacking off) to as high as fifty percent (50\%), but we reiterate, that there is no solid research in this area.

\section{CHANGES IN THE WORK}

Another major cause of productivity loss results from poor quality plans and specifications leading to an excessive number of Requests for Information (RFI's) and Change Orders (CO's) [2], [30, 31]. The research to date concludes that changes in the work resulting in change orders have a detrimental effect on construction productivity. In addition, the more change orders that are issued, the more exacerbated the effect becomes due to the cumulative impact [39].

Possibly the most influential study to date conducted on construction productivity is the Leonard Study of 1987 titled The Effects of Change Orders on Productivity [39]. The Leonard study found that when change orders amount to $25 \%$ of the original contract value (with no other major impact) productivity decreases by $20 \%$ on electrical and mechanical construction, and by $17 \%$ on civil and architectural work. When change orders amount to $50 \%$ of the original contract value productivity decreases by $31 \%$ on electrical and mechanical work, and $23 \%$ on civil and architectural.

Change orders are not isolated from the other activities on the job due to the interdependence of construction operations. A cumulative impact occurs with the addition of almost every change order (resulting in a ripple effect). [39]. Leonard found that major causes of productivity loss increased the loss exponentially. With one additional cause of productivity

\footnotetext{
${ }^{4}$ In this study, the researchers defined "rapid" increase in the workforce, as a doubling of the workforce from a steady state in any single work week, and continued until such time as the next steady state was reached. Though it has to be noted that this study was performed using data from only two projects, and the definition or "ramp-up" - a doubling of workforce in a week - is arbitrary and not universally accepted.
}

loss (delays or disruptions, adverse weather, etc.), productivity losses for electrical/mechanical work were increased by 11 to $14 \%$. With two additional causes, by 20 to $24 \%$. In civil and architectural work, productivity loss increased by $7 \%$ with one additional cause and an estimated $14 \%$ with two additional causes.

Myriad studies published from 1994 to 1999 discuss further methods for estimating and quantifying the effects of change orders. Among the most prominent of these studies was performed by Ibbs in 1995 [28]. They used the productivity index to compare productivities, and found that no project with "more than 25 percent change exhibited a productivity index better than the plan...[While] projects with less than six percent change, on average, experienced better productivity than planned" [28].

Ibbs also investigated the timing of change orders' issuance, which shows that changes issued later in a project are more detrimental than those of earlier issuance [29].

A host of additional publications that deal with the effects of change orders on labor productivity include work sponsored by the Construction Industry Institute at the University of Texas Austin [11], as well as other researchers [10], authors[13], and industry publications [48, 51, 49]. Finally, the Lee paper of 2004 [38] presents a different way to quantify labor productivity losses due to change orders. Instead of using the traditional regression model approach, they propose a decision-tree method that uses a series of questions to quantify the impact. The paper argues that regression methods can be inaccurate and overly-sensitive to noise.

\section{WEATHER}

Weather conditions can have an adverse impact on the duration and cost of construction activities [46]. Because weather is so erratic, it is not easy to predict the effects it will have on a project's productivity. However, it is not as difficult to quantify the effects of weather after the fact. This has led researches to varied, intense studies of many aspects of weather. Recent work, such as that of Moselhi, is allowing the construction industry to become more adept at predicting the impact of adverse weather [46].

Adverse weather can negatively affect productivity by halting work, which leads to disruption and fragmentation or by causing fatigue or increased stress (high/low temperatures). [Clapp 1966 cited in 21]). Other prominent publications that deal with estimating weather's impact on labor productivity include: [18], [35], and [22].

The drywall trade is generally performed indoors. While adverse weather can impact drywall phases indirectly, mainly through transportation difficulties, it was not found to be a major factor in the present study. 


\section{Proceedings of PICMET '16: Technology Management for Social Innovation}

\section{SPECIAL LABOR PRODUCTIVITY ISSUES IN STEEL FRAMING, INSTALLATION, AND FINISHING OF DRYWALL}

In its most basic form, there are two types of interior wall framing: primary (corridor or interference walls) and secondary (or partition walls). The primary walls must be installed before any mechanical, electrical, plumbing can be installed (collectively referred to as MEPs). The conflict between MEPs and drywall contractors is a major source of productivity loss. If the proper sequence is not adhered to, the drywall contractors will have difficulty accessing the work area. Additionally, each step of the process must pass inspection before the next step can commence. Inspections also apply to MEPs, and if not completed in an orderly fashion, the framing of secondary walls will be impacted. The sequence of installation for primary walls must be framing, inspection, top-down gypsum wallboard, inspection, followed by MEP installation.

Gypsum wallboard performs multiple functions in the built environment, most importantly, maintaining fire and sound ratings within the building. Design changes often complicate the installation process and threaten compliance with fire and sound ratings. The problem of access discussed in the framing section is magnified for installation. Prematurely installed MEPs may block access to other areas, which are ready for installation of wallboard.

Finishing of gypsum wallboard is completed in phases, coats, or sequences. A typical sequence may take between four to six passes including: fire taping, double or second coat, sanding of second coat, flushing of joints, sanding flush. This process is not only time consuming but volatile. The interior environment can have a dramatic effect on the finishing process. If not properly ventilated, the curing of the "mud" will cause the humidity to rise and prolong the drying process. By the time the finishing contractor is on the job, conflicts with MEPs should have been resolved, but congestion from other trades may present difficulties. Finishing contractors thrive when they have large areas on which to work, and productivity is impacted if left to work on bits and pieces at a time. Further, the use of automated tools helps to maximize productivity, and these tools cannot be used as effectively if work must be completed out-ofsequence or in small spaces.

\section{ANALYSES}

\section{A. DATA COLLECTION}

The principal sponser of this study assembled an expert panel of between eight and twelve industry executives and NWCB members to assist the research team in deriving factors to be studied, which is fairly common in studies of this type $[17,54,59]$. The panel met monthly over a several month period in the initial phase of the project, usually in conjunction with monthly board meetings. The number of participants varied depending on their schedules. Thirty eight variables, derived by the expert panel were tested using an ordinal Likert Scale ( 0 to $4^{5}$ ), along with continuous data such as $\operatorname{cost}^{6}$ and schedule growth. NWCB member companies provided the base data on paper survey forms which were submitted to the research team. In some instances the research team provided a student researcher to assist the contractors in filling out the forms to ensure the forms were being properly input. Each for was then scrutinized by the project team prior to inputting the data into the project database. Finally, once all of the data used in the study were in the database, the research team searched for anomalies and made personal contact with the data providers to clear up any issues. If problems remained or couldn't be resolved, the project was dropped from the database.

Contractors were encouraged to provide ten projects each, ranging from projects that went very well, to those which they considered disasters. Many of the smaller contractors only submitted a few surveys while several of the larger firms, with multiple offices in the west, provided dozens. Data collection began in June of 2006 and continued through November of $2008^{7}$. A total of 256 projects were submitted to the research team, 226 of which were ultimately used in the study. Many of the surveys were not complete, some of the jobs had not even finished when the company filled out the forms. Other project were simply too small to be considered in the analysis in part because they could have a disproportionate impact on the regression results. Finally the research team decided to eliminate jobs where the achieved productivity was more than double the estimated, because it was reasoned those projects would also have a disproportionate affect on the analysis.

More than 20 different construction operations representing a wide range of contractors submitted projects. Included in this group were three of the largest drywall contractors in the country, as well as large regional firms ${ }^{8}$, and smaller local firms.

The survey instrument itself had two separate parts: the first page contained quantitative project information such as the size of the project, original and final cost, and schedule, along with estimated and actual labor productivities for framing, hanging drywall, and taping \& finishing. The second, third, and fourth pages asked the contractor to rate the 38 variables with respect to their presence on the project from: None to Severe (where none $=0$ and severe $=4$ ). One survey sheet was provided to the contractors for each trade:

\footnotetext{
${ }^{5}$ Where 0 meant no impact and 4 meant severe impact to productivity.

${ }^{6}$ Cost growth is measured by Final Cost/Original Contract Value and is a measure of the proportion of Change Orders in a project.

${ }^{7}$ This paper was originally written in 2010, but a copyright dispute, which was not resolved until 2015 delayed the publication of this research.

${ }^{8}$ Those firms with multiple offices operating in two or more states.
} 
framing, hanging drywall, and taping and finishing drywall. All of the surveys were entered into an Excel spreadsheet by the research team.

\section{B. STATISTICAL ANALYSES}

As described earlier, the issue of examining construction productivity is complex. As such a variety of methods have been used to evaluate productivity in the industry. Early work attempted to use controlled experiments, such as the NECA [48] studies on electricians' piecework rates as a function of temperature. Unfortunately, it is not practical to conduct a meaningful experimental testbed to simulate the wide range of factors that affect drywall productivity. The present study used a detailed quantitative evaluation of real, completed drywall projects which is more consistent with the methods used in the majority of recent studies.

We were able to directly account for the design specific production rates by simply taking a ratio of actual production rates divided by the estimated production rates. For example, in the case of framing, we use linear feet per man-day (or man-hour) actually obtained vs. the estimated rate. If the estimated production rate was 100 linear feet per man-day but the actual rate was 80 , the relative productivity was then 0.80 (or $80 \%$ ). Our objective was to examine what explains this productivity loss.

A statistical analysis was conducted on a wide range of drywall projects. The large number of inter-related characteristics resulting in productivity loss required a combination of statistical techniques to be used. A separate set of evaluations was done for each of the three major drywalling functions: Framing of walls, hanging of wallboard, and taping \& finishing.

The first question to be answered is whether there is sufficient evidence to indicate a loss has occurred for which the next step would be to estimate the amount or quantum of loss. The key function of this section is not to quantify the productivity loss, but instead to determine whether or not the productivity loss occurred as a result of conditions, which are the responsibility of the general contractor or owner. In this case, the dependent variable is not continuously valued as would be productivity but is instead categorical, a loss has occurred or it has not occurred.

Three steps are used in this analysis for all trades: metal stud framing, hanging, and taping and finishing of drywall. First, each variable was regressed against productivity, followed by an evaluation of the Master Correlation Matrix, finally, various variables were combined in order to reduce the overall number of variables and inter-correlation of variables.

\section{SIMPLE SINGLE LINEAR REGRESSIONS}

The simple linear regression step was used to find which causes and effects have the strongest relationships productivity loss and validate that the responses were consistent with the literature on productivity loss presented earlier in this report. In this step, each of the 35 characteristics and 3 yes/no questions are regressed separately against the relative productivity (actual divided by estimated). This means there were 38 separate regressions for each of the three relative productivities: Framing, hanging, and taping \& finishing. Conceptually, this means plotting all of the projects with relative productivity on the vertical axis and the characteristic on the horizontal axis. Regression is then a systematic process for drawing a line that best "fits" the data. If the line is "tilted" downwards, this reflects a negative slope and it indicates an increase in the characteristic is associated with decreased productivity.

The results of these regressions is found in Table 1. Note that of the 35 Factors not associated with the presence of schedule management, all but two of the Factors were associated with a negative impact to productivity. Nearly all of these Factor relationships were statistically significant to the $99^{\text {th }}$ percentile, and all but three were significant at the $95^{\text {th }}$ percentile. It is als notable that in all but one instance, supplying the subcontractors with Three-week Look-ahead schedules, the overall project schedule, and schedule updates were associated with positive gains in productivity.

\section{MASTER CORRELATION MATRIX}

The first of the statistical analyses undertaken for this study was to take all 38 variables for each of the three trades (metal stud framing, hanging drywall, and taping and finishing), and prepare a master correlation matrix for each.

The second step was to examine how all 38 of the characteristics were related. We created a matrix of 38 rows and 38 columns to show the correlation between each characteristic and each of the other characteristics. Correlations can have values from negative one to positive one. Positive correlation between two characteristics, A and $\mathrm{B}$, indicates when $\mathrm{A}$ is higher than average, then $\mathrm{B}$ is also likely to be higher than average, and when $\mathrm{A}$ is lower than average, then $\mathrm{B}$ is also likely to be lower than average. A correlation of zero between $\mathrm{A}$ and $\mathrm{B}$, means that a project with a high value of $\mathrm{A}$ is no more likely to have a high value of $\mathrm{B}$ than any other project. The correlation matrix is very useful for examining how these 38 characteristics are interrelated. While this correlation matrix was large with 1,444 values (38x38), for each of the 3 functions, patterns of strong relationships between characteristics were readily apparent. The Master Correlation Matrix for Metal Stud Framing in presented in Table 2 below, though all three of the Master Correlation Matricies were found to be substantially similar. 
TABLE 1 RESULTS OF SINGLE LINEAR REGRESSIONS OF IMPACT FACTORS AGAINST PRODUCTIVITY

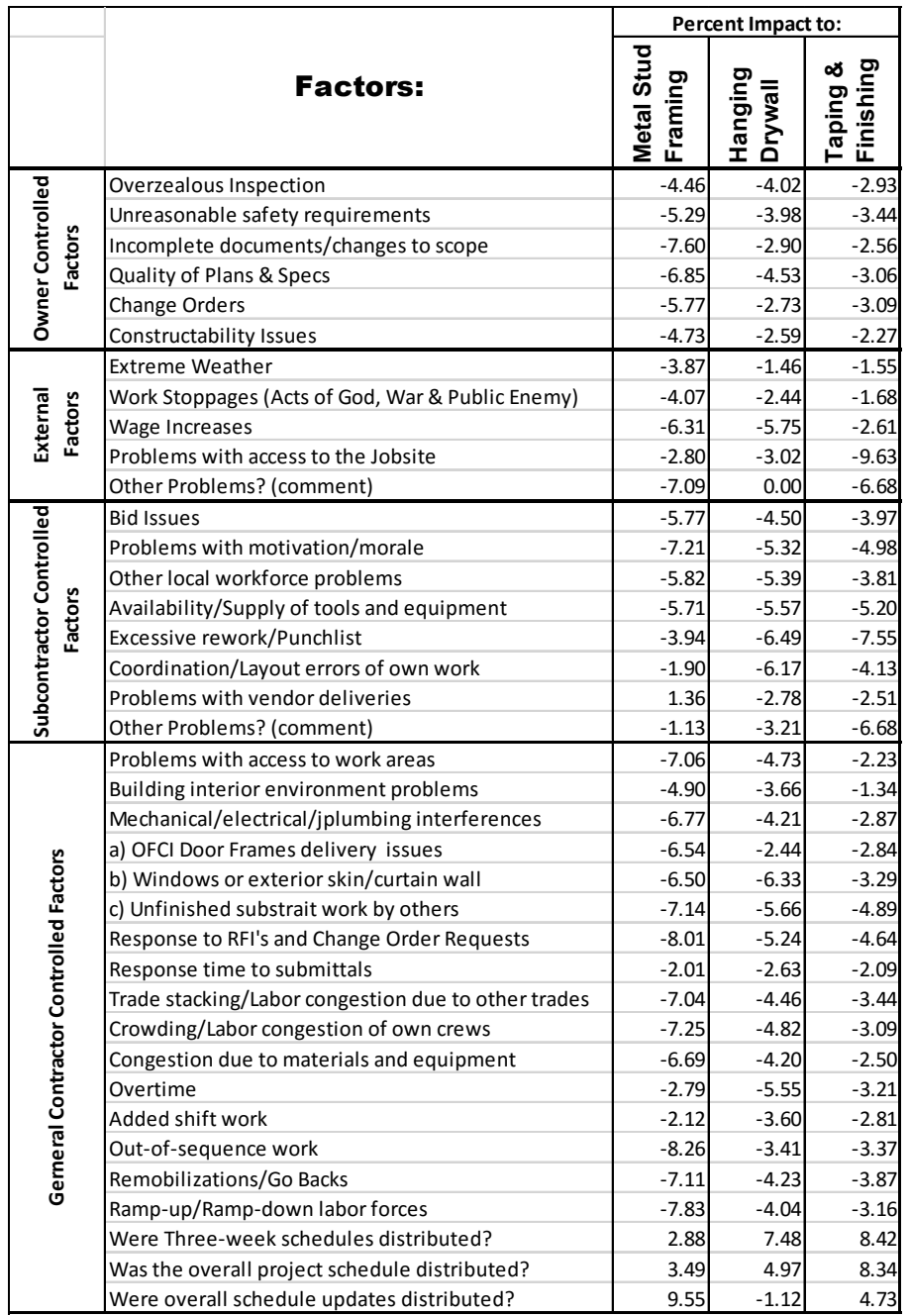

TABLE 2 METAL STUD FRAMING MASTER CORRELATION MATRIX

\begin{tabular}{|c|c|c|c|c|c|c|c|c|c|c|c|c|c|c|c|c|c|c|c|c|c|c|c|c|c|c|c|c|c|c|c|c|c|c|c|c|c|c|}
\hline & & \multicolumn{6}{|c|}{ Owner Controlled Factors } & \multicolumn{6}{|c|}{ Environmental Factors } & \multicolumn{8}{|c|}{ Subcontractor Controlled Factors } & \multicolumn{16}{|c|}{ General Contractor Controlled Factors } & \\
\hline & & \begin{tabular}{|l}
$\bar{\delta}$ \\
$\sum_{\mu}^{\prime}$
\end{tabular} & $\begin{array}{l}\infty \\
\sum_{3}^{\prime} \\
\sum^{\prime}\end{array}$ & 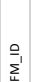 & & $\begin{array}{l}\stackrel{0}{0} \\
\Sigma_{u}^{\prime}\end{array}$ & $\begin{array}{l}\overline{\bar{v}}_{1} \\
\bar{\Sigma}_{u}^{\prime}\end{array}$ & $\begin{array}{l}3 \\
\sum^{\prime}\end{array}$ & $\begin{array}{l}3 \\
\vdots \\
\Sigma\end{array}$ & $\begin{array}{l}3 \\
3 \\
\Sigma\end{array}$ & & & 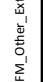 & 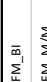 & $\begin{array}{l}\sum \\
\sum_{1} \\
\sum_{u}\end{array}$ & 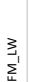 & 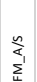 & $\begin{array}{l}\frac{3}{\mu_{4}} \\
\sum^{1}\end{array}$ & $\begin{array}{l}\tilde{u}_{u} \\
\frac{\mathrm{J}}{\mathrm{u}}\end{array}$ & $\begin{array}{l}S_{s^{\prime}} \\
\end{array}$ & 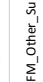 & 吕 & & 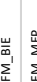 & $\sum_{\frac{1}{\sum_{i}^{\prime}}}$ & 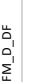 & $\begin{array}{l}3 \\
a_{1}^{\prime} \\
s^{1}\end{array}$ & $\begin{array}{l}n \\
z_{1} \\
\vdots \\
\sum^{\prime}\end{array}$ & $\begin{array}{l}\frac{\bar{u}}{\underline{\alpha}} \\
\alpha_{1}^{\prime} \\
\Sigma_{u}^{\prime}\end{array}$ & 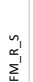 & $\begin{array}{l}F_{1}^{\prime} \\
\sum_{u}^{1}\end{array}$ & $\begin{array}{l}y_{1} \\
\sum_{u}^{\prime}\end{array}$ & $\sum_{i}^{\prime}$ & 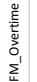 & 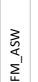 & & 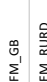 & \\
\hline Overzealous Inspection & FM_Ol & & & 0.45 & & 0.23 & 0.41 & 0.3. & 20.2 & & 330. & & 0.16 & & & & & & & 110.25 & $\begin{array}{ll}50.09 \\
\end{array}$ & & & & & & & & & & & & & & & & 0.420 .4 & \\
\hline & FM_USR & 0.58 & & & & & 0.36 & 0.3 & 60.3 & & 350 & & 0.06 & 0.090. & 0.270 & 0.28 & 0.43 & & 310.42 & 20.46 & 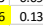 & & & & & .240 & 0.38 & 0.39 & & 0.43 & 0.36 & & & & & & & \\
\hline ccope & FM_ID & 0.45 & 0.38 & & & 0.55 & & 0.3 & 340.2 & 20.3 & 300. & & 0.16 & 0.170. & $0.39 \mathrm{c}$ & 0.12 & 0.07 & & 310.36 & 60.16 & $\begin{array}{ll}6 & 0.11 \\
\end{array}$ & & .530. & .350. & 1560. & 0.270 & 0.25 & 0.30 & 0.53 & 0.39 & 0.55 & 0.54 & 0.55 & $0.41 \mathrm{C}$ & 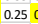 & & & \\
\hline ans 8 & FM_QOP & 0.36 & 0.28 & & & 0.50 & 0.50 & 0.1 & 30.0 & & 200. & & 0.07 & 0.200. & $0.36 \mathrm{c}$ & 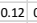 & 0.17 & & 270.24 & 40.13 & 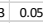 & & 400. & .160. & & 0.260 & 0.21 & 0.24 & 0.38 & 0.27 & 0.42 & 0.39 & 0.35 & 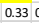 & $0.15 \mathrm{c}$ & & 0.440 .3 & \\
\hline & & 0.23 & 0.18 & 0.55 & & & 0.60 & 0.2 & 260.1 & 80.3 & 310. & & 0.11 & 0.230. & 0.430 & $0.18-1$ & -0.11 & & 300.07 & 70.06 & \begin{tabular}{l|l}
6 & 0.12 \\
\end{tabular} & & 380 & & & $0.21-$ & & & & & & & & & & & & \\
\hline ty Issues & & 0.41 & 0.36 & & & & & 0.2 & 260.1 & 150.2 & 280 & & 0.34 & 0.270. & & & -0.02 & & & & 0.26 & & & & & & & & & & & & & & & & & \\
\hline Extreme Weather & FM_EW & 0.32 & 0.36 & 0.34 & & 0.26 & 0.26 & & 0.4 & & 480. & & 0.22 & & 0.390 & 0.144 & 0.18 & & & 20.28 & $\begin{array}{lll}8 & 0.20 \\
\end{array}$ & & 360 & & & & 0.33 & & & & & & & & & & & \\
\hline Work Stoppages (Acts of God, War \& Public Enemy) & FM_WS & 0.26 & & 0.22 & & 0.18 & 0.15 & 0.45 & & & 490. & & 0.33 & & 0.230 & 0.30 & & & 10.22 & 20.21 & $\begin{array}{lll}1 & 0.24 \\
\end{array}$ & & & & & & & & & & & & & 0.26 & & & & \\
\hline ge Increases & FM_WI & 0.33 & 0.35 & & & 0.31 & 0.28 & & 180.4 & & & & 0.20 & 0.150. & $0.40 \mathrm{O}$ & 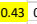 & 0.24 & & 220.22 & 20.18 & \begin{tabular}{l|l}
8 & 0.08 \\
\end{tabular} & & & & & 0.050 & 0.31 & & & & & & & 0.36 & & & & \\
\hline Problems with access to the Jobsite & FM_PJA & 0.35 & 0.42 & 0.33 & 0.25 & 0.40 & 0.42 & 0.2 & 290.2 & & & & 0.26 & 0.180. & $0.50 \mathrm{C}$ & 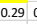 & 0.10 & 0.17 & 170.28 & 80.42 & 20.19 & & .590. & .360 .3 & 340 & $0.10 \mathrm{c}$ & 0.03 & & 0.20 & 0.17 & 0.36 & & & 0.37 & $0.38 \mathrm{C}$ & 0.33 & & \\
\hline Other Problems? (comment) & FM_Other_Ex & 0.16 & 0.06 & 0.16 & & 0.11 & 0.34 & 0.2 & 20.3 & & 200. & & & $0.330 .8 \mathrm{r}(\mathrm{z})$ & 0.260 & $0.17-1$ & -0.08 & 80.07 & 770.01 & $1-0.13$ & $\begin{array}{ll}3 & 0.30 \\
\end{array}$ & & 130. & & 200 & 0.130 & 0.08 & 0.13 & & 0.19 & & & & 0.13 & $0.14 \mathrm{C}$ & & 0.170 & \\
\hline Bid Issues & FM_BI & 0.07 & 0.09 & 0.17 & 0.20 & 0.23 & 0.27 & 0.1 & 60.1 & & 150. & & 0.33 & & & 0.350 & 0.15 & 0.37 & 770.29 & 90.16 & $\begin{array}{ll}6 & 0.21 \\
\end{array}$ & & 180. & 190.2 & & .230 & 0.20 & & & 0.26 & 0.33 & & & 0.09 & $0.09 \mathrm{C}$ & & 0.300. & \\
\hline blems with motivation/morale & $\mathrm{M} / \mathrm{M}$ & 0.28 & 0.27 & 0.39 & & 0.43 & 0.49 & 0.35 & 990.2 & & & & 0.26 & 0.39 & & 0.48 & 0.22 & 0.44 & 140.43 & 30.36 & $\begin{array}{cc}6 & 0.28 \\
\end{array}$ & & & & & 0.390 & 0.32 & 0.41 & & 0.35 & & & & 0.35 & & & & \\
\hline er local workforce problems & C.LW & 0.27 & & & & 0.18 & & 0.4 & & & & & 0.17 & 0.350. & 0.48 & & 0.36 & & & 60.37 & 70.20 & & & & & & 0.38 & & & 0.18 & & & & & & & & \\
\hline ply of tools and equipment & $\mathrm{A} / \mathrm{S}$ & & & & & -0.11 & -0.02 & & & & & & -0.08 & 0.150. & & & & 0.38 & & & \begin{tabular}{l|l|}
8 & 0.13 \\
\end{tabular} & & & & & & & & & & & & & & & & & \\
\hline & CERW & 0.26 & & & & 0.30 & 0.26 & & & & & & 0.07 & 0.370. & & & 0.38 & & & & 50.20 & & & & & & & & & & & & & & & & & \\
\hline & & & & 0.36 & & & & & & & & & 0.01 & 0.290. & & & & & & 0.45 & & & & & & & & & & & & & & & & & & \\
\hline & & 0.25 & & 0.16 & & 0.06 & 0.10 & 0.28 & 280.2 & & 180. & & -0.13 & 0.160 & & 0.37 & 0.38 & 80.45 & 150.45 & & 0.18 & & .560 & & & & & & & 0.33 & 0.32 & & 0.48 & 0.42 & & & 320. & \\
\hline & FM_Othe & 10.09 & 0.13 & 0.11 & 0.05 & 0.12 & 0.26 & 0.2 & 20.2 & 40.0 & 080. & & 0.30 & 0.210 .2 & 0.280 & 0.20 & 0.13 & 30.20 & 200.19 & & & & 130. & .260. & 130 & 0.230 & & & & & 0.18 & 0.18 & & 0.17 & & & & \\
\hline & & 0.47 & 0.49 & 0.53 & 0.40 & 0.38 & 0.45 & 0.36 & 360.2 & 280.3 & 350. & & 0.13 & 0.180. & 0.490 & 0.300 & 0.27 & 70.39 & 990.40 & 0.56 & $5 \quad 0.13$ & & & .430. & 1590. & 0.350 & & & & 0.31 & & & & 0.51 & 0.380 & 5 & & \\
\hline & FM_BIE & 0.27 & 0.26 & 0.35 & 0.16 & 0.41 & $\begin{array}{l}0.37 \\
0.37\end{array}$ & 0.6 & 0.4 & 430.4 & .410 & & 0.17 & 0.190 & 0.460 & $0.31 \mathrm{c}$ & 0.16 & 50.30 & 300.19 & 90.16 & $\begin{array}{l}0.13 \\
5\end{array} 0.26$ & & 43 & & 370 & 0.28 & 0.40 & & 0.28 & & 0.38 & 0. & 0.31 & & & & 00 & \\
\hline ical/electrical/jplumbing inter & FM_MEP & 0.30 & 0.37 & & & 0.35 & & & 90.2 & & & & 0.20 & 0.290. & & 0.25 & 0.17 & & & & 0.13 & & 1.590. & & & 0.570 & 0.50 & & & & & & & & 0.23 & & & \\
\hline FFCI Door Frames delivery issues & 1-D_DF & 0.18 & 0.24 & & & & 0.21 & & & & & & 0.13 & 0.230. & & 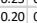 & 0.27 & & 130.42 & 20.22 & 20.23 & & & .280. & & & 0.56 & & & & & & 0.49 & & & & & \\
\hline sor exterior ski & $\mathrm{F}$ & 0.30 & & 0.25 & & -0.03 & & & & & & & 0.08 & 0.200. & & 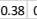 & 0.38 & & & 30.12 & \begin{tabular}{l|l}
2 & 0.19 \\
\end{tabular} & & 260. & $.40 \mathrm{c}$ & & & & & & & & & & & $0.07 \mathrm{C}$ & & & \\
\hline c) Unfinished substrait work by others & $\mathrm{FN}$ & 0.34 & & 0.30 & & 0.00 & & & 30.1 & & & & 0.13 & 0.180. & & $0.32 \mathrm{C}-2000$ & 0.30 & & 410.44 & 40.27 & $\begin{array}{l}7 \\
0.13\end{array}$ & & & .290 .6 & & & & & 0.51 & & & & & & $0.17 \mathrm{c}$ & & & \\
\hline onse to RFI's and Char & R RFI & 0.35 & 0.34 & 0.53 & & 0.23 & 0.44 & 0.2 & 30.2 & & & & 0.20 & 0.310. & & 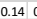 & 0.22 & 20.50 & 50.41 & 10.27 & $\begin{array}{ll}7 & 0.17 \\
\end{array}$ & & & .28 & & & 0.46 & 0.51 & & & & & & 0.32 & & & 0.550 & \\
\hline oonse time to submittals & FMRS & 0.37 & 0.43 & 0.39 & 0.27 & 0.06 & 0.43 & 0.2 & 30.2 & & .170. & & 0.19 & 0.260. & & 0.18 & 0.29 & 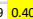 & 100.43 & 30.33 & $\begin{array}{ll}30.25 \\
\end{array}$ & & & .200. & & 0.380 & 0.42 & & & & & & & & & & & \\
\hline to othe & & & 0.36 & 0.55 & & & & 0.3 & 10.2 & & & & & & & 0.22 & 0.21 & & & & 20.18 & & & & & 0.560 & & & 0.52 & & & & & & 0.310 & & & \\
\hline & FM L LC & 0.34 & 0.44 & 0.54 & & 0.33 & 0.49 & 0.2 & 90.2 & & 250. & & 0.15 & 0.300 & & 0.27 & 0.25 & & 120.44 & 40.40 & 0.18 & & & & & 0.440 & & & & & & & & & 0.43 & & & \\
\hline Jue to materials & $F M C$ & 0.39 & 0.43 & 0.55 & & 0.35 & 0.46 & 0.3 & 20.2 & & 250 & & 0.21 & 0.220 & & 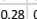 & 0.19 & 90.40 & 100.40 & 0.48 & 0.21 & & & 31 & & 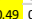 & & & & & & & & & & & & \\
\hline & & & & & & 0.30 & & & & & & & 0.13 & 0.090 & & 0.28 & 0.30 & & $\begin{array}{lll}30 & 0.33\end{array}$ & 20.42 & & & & & & 0.18 & & & & & & & 0.49 & & & & 0.440 & \\
\hline & & & & & & & & & & & & & & & & & & & & & & & 380. & & & & & & & & & & & 0.46 & & & & \\
\hline & & & & & & 0.31 & 0.42 & & & & 300 & & 0.14 & & & 0.19 & 0.08 & & & $\begin{array}{ll}6 \\
6 & 0.41\end{array}$ & \begin{tabular}{|l|l|}
5 & 0.13
\end{tabular} & & & & & & & & & & & & & & & & & \\
\hline & & & & & & & & & & & & & 0.17 & & & 0.28 & & & & 00.32 & & & & & & & & & & & & & & & & & & \\
\hline & FM RURD & & & 0.57 & & 0.34 & & & & & & & 0.16 & 40. & & 0.36 & 0.34 & & & 80.33 & \begin{tabular}{|c|c|c|}
3 & 0.25
\end{tabular} & & & 40 & & & 0.50 & & 0.50 & 0.44 & & & & & 0.42 & & & \\
\hline
\end{tabular}


Correlations that are between 0.40 and 0.60 are highlighted in yellow, those which are above 0.6 are highlighted in red. The key observation of these correlation matrices was the high levels of correlation between certain groups of variables, which appeared to be divided by type. These "types" appeared to fall into three groups: Root Causes of labor productivity impacts ("Causes"); Changes in the execution of the work or "Effects"; and Direct causes of negative labor productivity impact ("Directs"). Nearly all of the Causes, Effects, and Directs were positively correlated with each other and negatively correlated with labor productivity. For example, in the hanging drywall correlation matrix, the three congestion related variables: Trade Stacking, Crowding, and Congestion due to Materials were intra-correlated at 0.8 and 0.9 , meaning that their impact scores matched on greater than eighty percent $(80 \%)$ of the responses. These three variables were also highly correlated with the "Mechanical/Electrical/Plumbing Interference" variable $(0.77,0.65$, and 0.68 respectively) and the "Problematic Access to Specific Areas" variable (0.61, 0.63, and 0.66 respectively).

The three work fragmentation variables: Out-of-sequence Work, Remobilizations/Go-backs, and Ramp up/Ramp downs, were also highly intra-correlated, and also highly correlated with the "Mechanical/Electrical/Plumbing Interference" variable $(0.61,0.70$, and 0.62 respectively) and the "Problematic Access to Specific Areas" variable (0.54, 0.60 , and 0.60 respectively).

In addition, the fragmentation variables were highly correlated with four owner project management variables: Incomplete Documents/Changes to Scope, Quality of Plans, Change Orders, and Constructability Issues. Two other project management variables: Response Time to RFI's and Change Orders, and Response to Submittals, were also highly correlated to both the congestion and fragmentation variables. Not surprisingly, the Incomplete Documents/Changes to Scope, Quality of Plans, Change Orders, and Constructability Issues variables were found to be highly intra-correlated, and positively correlated, though less highly, with the other project management variables: Response Time to RFI's and Change Orders, and Response to Submittals. These observations were consistent with both Framing and Taping \& Finishing variables as well.

These observations have led the research team to conclude that several of the variables in the study, derived by the expert panel, can be grouped into the different classifications discussed above, namely: Causes, Effects, and Directs. In addition, these can be further separated out into descriptive types, such as: fragmentation, congestion, and project management variables.

\section{COMBINING OF FACTORS}

Given the high level of inter and intra-group correlations, and the large number of Factors in the original model, it was determined to combine highly inter-correlated factors to reduce the overall number of factors and increase the average power of each factor's impact. The 35 factors not associated with scheduling practices, were combined into ten factors, with the subcontractor controlled factors deleted 9 . Combining of factors was done by taking the average of the factors that were combined.

The Owner controlled factors were reduced to two: Owner Interference which was the average of the Over Zealous Inspection and the Unreasonable Safety Requirements; and Quality of Design Documents which was the average of Incomplete Documents/Changes in Scope, Quality of Plans \& Specs, Change Orders and Constructability Issues. All five of the External Factors were averaged into one. The General Contractor contolled factors were combined into the following factors: Access to the Work, Owner/General Contractor Supplied Materials, General Contractor Response to Requests for Information (RFI's) and Submittals, Congestion, Overtime, Added Shift Work, and Work Fragmentation.

These new combined factors were regressed against relative productivity for the three trades and the results are presented in

TABLE 3 COMBINED FACTORS IMPACT ON PRODUCTIVITY

\begin{tabular}{|c|c|c|c|}
\hline Combined Factors & 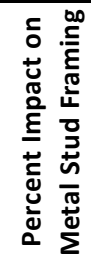 & 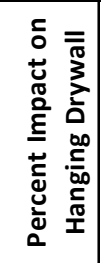 & 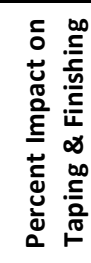 \\
\hline Owner Interference & -8.8 & -7.36 & -5.11 \\
\hline Quality of Design Documents & -12.1 & -9.42 & -7.31 \\
\hline External Factors & -9.5 & -4.6 & -3.29 \\
\hline Access to the Work & -9.56 & -7.6 & -4.27 \\
\hline Owner/GC Supplied Materials & -8.06 & -6.88 & -4.72 \\
\hline GC Response to RFIs \& Submittals & -6.64 & -5.5 & -5.97 \\
\hline Congestion & -7.92 & -6.1 & -8.47 \\
\hline Overtime & -2.8 & -5.6 & -3.91 \\
\hline Added Shift Work & -1.97 & -2.5 & -3.02 \\
\hline Work Fragmentation & -9.2 & -6.63 & -5.62 \\
\hline
\end{tabular}

Eight of the ten framing factors were statistically significant above the $99 \%$ level, with Overtime and Added Shift work closer to the $90 \%$ level. Eight of the ten hanging factors were also found to be statistically significant at the 99\% leve or above, with only External Factors (around 95\%) and Added Shift Work (below 90\%) fell below that mark. Only five of the ten taping and finishing factors were found to be statistically significant at or above the $99 \%$ level, however four were found to be significant at the $95 \%$ level

\footnotetext{
${ }^{9}$ Subcontractor controlled factors were deleted because this ultimately is a study of how factors that are not within the subcontractor's control affect subcontractor trade labor productivity.
} 
and only External Factors fell below 90\% statistically significant.

Note again that the factors were rated on a scale of zero, meaning no impact, to four, meaning severe impact. This means that the average maximum impact for any of the factors above would be the Percent Impact given in the table above multiplied by four. For example, the greatest impact in framing would be a four (4) on Quality of Design Documents $(-12.1 \%)$ which would result in an expected impact of $-48.4 \%$ reduction in productivity! This would then be applied to the total framing labor.

\section{RESULTS}

This work was the first major study of an entire sector of the construction industry since the updates to the early 1960's NECA studies by Hanna [23] in 2004. It is the first major study in the Metal Stud Framing and Drywall industry and included more projects 226 than any previous industry study ${ }^{10}$.

The hypothesis, based upon the literature review, that the 35 proposed impact factors were expected to be associated with decreased productivity was shown by data collection and statistical analysis to be the case. The 35 impact factors generally had the expected relationship across all three major functions: framing, hanging, and taping \& finishing. This serves in part as a validation of the approach and responses. The three yes/no questions for each of the drywall functions also generally had the expected direction, positively correlated with productivity, which was also the case.

The correlation matrices show the inter-relationship amongst the 35 impact factors. This too is consistent with the literature review. The correlation matrix and the statistical analysis showed a very high level of inter-correlation between many of the variables, so a decision was made to reduce the 38 variables into 10 factors of highly correlated variables. This will assist contractors using this study to assess labor productivity impacts on their specific projects, which they might otherwise attempt to inappropriately combine.

The crux of the results section here is providing a tool demonstrating the relationship between certain factors and a reduction in productivity. If these factors arise on a construction project, the contractor can proceed to calculating the estimated level of impact it might be expected to incur. However, it should be noted that the results are the "best fit" or "average" impact, so a contractors actual impact could be greater or less than the figures shown above.

The fundamental conclusion and results of this study are that factors outside of the subcontractor's control, including but not limited to Quality of Design Docments, Congestion and Fragmentation of the work, can have a negative impact

\footnotetext{
${ }^{10}$ The MCAA study is not based on any actual projects, it is merely the
} collected opinions of an unknown number of industry executives. on the Metal Stud Framing and Drywall contractor's labor productivity. As a result, the contractor may be entitled to seek a remedy of compensation or additional time from the general contractor or owner on the project.

\section{REFERENCES}

[1] T. Adeleye, M. Huang, Z. Huang, and L. Sun, "Predicting Loss for Large Construction Companies," Journal of Construction Engineering and Management, vol. 139, pp. 1224, 2013.

[2] J. J. Adrian, Construction Claims: A Quantitative Approach. Champaign, Illinois: Stripes Publishing L.L.C., 1993.

[3] J. J. Adrian, Quantitative Methods in Construction Management. New York, NY: American Elsevier Publishing Company, Inc., 1973.

[4] A. M. Alashwal and P. S.-W. Fong, "Empirical Study to Determine Fragmentation of Construction Projects," Journal of Construction Engineering and Management, vol. 141, pp. 04015016, 2015.

[5] P. C. L. Anastasopoulos, S.;Bhargava, A.;Mannering, F. L., "Empirical Assessment of the Likelihood and Duration of Highway Project Time Delays," Journal of Construction Engineering and Management-Asce, vol. 138, pp. 390, 2012.

[6] M. Arashpour, R. Wakefield, N. Blismas, and E. W. M. Lee, "Analysis of Disruptions Caused by Construction Field Rework on Productivity in Residential Projects," Journal of Construction Engineering and Management, vol. 140, pp. 04013053, 2014.

[7] J. Bröchner and T. Olofsson, "Construction Productivity Measures for Innovation Projects," Journal of Construction Engineering and Management, vol. 138, pp. 670, 2012.

[8] CII, "Leading Indicators During Execution," 2006.

[9] CII, "Quantitative Effects of Project Change," The Construction Industry Institute

The University of Texas at Austin 1995.

[10] G. M. Coffman, "Effect of change orders on labor productivity," presented at Proceedings of the 1997 5th ASCE Construction Congress, Oct 4-8 1997, Minneapolis, MN, USA, 1997.

[11] Construction-Industry-Institute, "The Impact of Changes on Construction Cost and Schedule," The University of Texas at Austin, Austin, Texas 1990.

[12] Construction-Industry-Institute, "Quantifying the Cumulative Impact of Change Orders for Electrical and Mechanical Contractors," The University of Texas at Austin, Austin, Texas 2000.

[13] R. F. Cushman and S. D. Butler, Construction Change Order Claims. New York, New York: Aspen Publishing (formally published by John Wiley \& Sons, Inc.), 1994.

[14] Department-of-Labor, "Hours of Work and Output, Bulletin No. 917," B.L.S., Washington, D.C. 1947.

[15] J. G. Everett and S. H. Farghal, "Learning Curve Predictors for Construction Field Operations," Journal of Construction Engineering and Management, vol. 120, 1994.

[16] S. L. Fan, "Modified Time Impact Analysis Method," Journal of Construction Engineering and Management-Asce, vol. 138, pp. 227, 2012.

[17] T. Gao, S. Ergan, B. Akinci, and J. H. Garrett, "Proactive Productivity Management at Job Sites: Understanding Characteristics of Assumptions Made for Construction Processes during Planning Based on Case Studies and Interviews," Journal of Construction Engineering and Management, vol. 140, pp. 04013054, 2014.

[18] C. T. Grimm and N. K. Wagner, "Weather Effects on Masonry Productivity," ASCE Journal of the Construction Division, vol. 100(CO3), pp. 319, 1974.

[19] H.R. Thomas, C.T. Mathews, and J. G. Ward, "Learning Curve Models of Construction Productivity," Journal of Construction Engineering and Management, vol. 112, 1986.

[20] K. Hajifathalian, B. W. Wambeke, M. Liu, and S. M. Hsiang, "Effects of Production Control Strategy and Duration Variance on Productivity and Work in Process: Simulation-Based Investigation," Journal of Construction Engineering and Management, vol. 138, pp. 1035, 2012. 
[21] D. W. Halligan, L. A. Demsetz, and J. D. Brown, "Action-response model and loss of productivity in construction," Journal of Construction Engineering and Management, vol. v 120, pp. 47, 1994.

[22] D. E. Hancher; and H. A. Abd-Elkhalek, "The effect of hot weather on construction labor productivity and costs," Cost Engineering, vol. 40, pp. 32, 1998.

[23] A. S. Hanna, "Factors Affecting Labor Productivity for Electrical Contractors," The Electrical Contracting Foundation for Electrical Contractors, pp. 31, 2004.

[24] A. S. Hanna, "Impact of Overtime on Electrical Labor Productivity: Measured Mile Approach," University of Wisconsin_Madison 2011.

[25] A. S. Hanna, J. S. Russell, E. V. Nordheim, and M. J. Bruggink, "Impact of change orders on labor efficiency for electrical construction," Journal of Construction Engineering and Management, vol. 125 , pp. 224, 1999 b.

[26] A. S. Hanna, E. J. Tadt, and G. C. Whited, "Request for Information: Benchmarks and Metrics for Major Highway Projects," Journal of Construction Engineering and Management, vol. 138, pp. 1347, 2012.

[27] A. S. Hanna, C. S. Taylor, and K. T. Sullivan, "Impact of Extended Overtime on Construction Labor Productivity," Journal of Construction Engineering \& Management, vol. 131, pp. 734, 2005.

[28] C. W. Ibbs and W. E. Allen, "Quantitative impacts of project change," in Construction Industry Institute. Austin, Texas: University of Texas at Austin, 1995.

[29] C. W. Ibbs, Y. H. Kwak, T. Ng, and A. Murat Odabasi, "Project delivery systems and project change: Quantitative analysis," Journal of Construction Engineering and Management, vol. 129, pp. 382, 2003.

[30] C. W. Ibbs, L. D. Nguyen, and S. Lee, "Quantified impacts of project change," Journal of Professional Issues in Engineering Education and Practice, vol. 133, pp. 45, 2007.

[31] W. Ibbs, "Impact of change's timing on labor productivity," Journal of Construction Engineering and Management, vol. 131, 2005.

[32] W. Ibbs, L. D. Nguyen, and L. Simonian, "Concurrent Delays and Apportionment of Damages," Journal of Construction Engineering \& Management, vol. 137, pp. 119, 2011.

[33] A. M. Jarkas and C. G. Bitar, "Factors Affecting Construction Labor Productivity in Kuwait," Journal of Construction Engineering and Management, vol. 138, pp. 811, 2012.

[34] F. Jordan Srour, D. Kiomjian, and I. Srour, "Learning Curves in Construction: A Critical Review and New Model," Journal of Construction Engineering and Management, vol. 142, pp. 06015004, 2016.

[35] E. Koehn and G. Brown, "Climatic Effects on Construction," Journal of Construction Engineering and Management, vol. 111, pp. 129, 1985.

[36] M. S. Konchar and V. Sanvido, "Comparison of U.S. project delivery systems," Journal of Construction Engineering and Management, vol. 124 , pp. $435,1998$.

[37] J. C. Kovars, C. W. Ibbs, and P. L. Stynchomb, "Pros and Cons of Using Industry Studies to Quantify Loss of Labor Productivity," Construction Lawyer: Journal of the ABA Forum on Construction Law, vol. 36, pp. 6, 2016.

[38] M. J. H. Lee, Awad S.;Loh, Wei Yin, "Decision Tree Approach to Classify and Quantify Cumulative Impact of Change Orders on Productivity," Journal of Computing in Civil Engineering, vol. 18, pp. 132,2004

[39] C. Leonard, "The Effect of Change Orders on Productivity," Concordia University, Montreal, Quebec, Canada 1987.

[40] H. Li, D. Arditi, and Z. Wang, "Factors That Affect Transaction Costs in Construction Projects," Journal of Construction Engineering and Management, vol. 139, pp. 60, 2013.

[41] W. F. Maloney, "Motivation in construction: A review," vol. 107, pp. 641,1981

[42] W. F. Maloney, "Productivity improvement: The influence of labor," Journal of Construction Engineering and Management, vol. 109, pp. 321, 1983.

[43] W. F. Maloney and J. M. McFillen, "Research needs in construction worker performance," vol. 109, pp. 245, 1983.

[44] MCAA, "Change Orders, Productivity, Overtime," MCAA 2005.

[45] D. F. McDonald and J. G. Zack, "Estimating Lost Labor Productivity in Consturuction Claims," Morganstown, WV 2003.
[46] O. Moselhi, D. Gong, and K. El-Rayes, "Estimating weather impact on the duration of construction activities," Canadian Journal of Civil Engineering, vol. 24, pp. 359, 1997.

[47] O. L. Moselhi, C. Leonard, and P. Fazio, "Impact of change orders on construction productivity," Canadian Journal of Civil Engineering, vol. 18, pp. 484, 1991.

[48] NECA, "The Effect of Temperature on Productivity," National Electrical Contractors Association Inc., Washington, D.C. 1974.

[49] NECA, "Overtime and Productivity in Electrical Construction," National Electrical Contractors Association, Washington, D.C. 1989.

[50] NECA, "Overtime and Productivity in Electrical Construction," NECA 1989.

[51] NECA, "Overtime and Productivity in electrical construction," National Electrical Contractors Association, Inc., Washington, D.C. 1969.

[52] L. D. Nguyen, D. H. Phan, and L. C. M. Tang, "Simulating Construction Duration for Multistory Buildings with Controlling Activities," Journal of Construction Engineering and Management, vol. 139, pp. 951, 2013.

[53] D. A. Norfleet, "Loss of learning in disruption claims," presented at 2004 AACE International Transactions - 48th AACE International Annual Meeting, Washington, DC, United States, 2004.

[54] W. Orabi and K. El-Rayes, "Critical Success Factors for Different Components of Construction Projects," Journal of Construction Engineering and Management, vol. 138, pp. 520, 2012.

[55] U. Ranasinghe, J. Ruwanpura, and X. Liu, "Streamlining the Construction Productivity Improvement Process with the Proposed Role of a Construction Productivity Improvement Officer," Journal of Construction Engineering and Management, vol. 138, pp. 697, 2012.

[56] D. Riley and V. Sanvido, "Space planning for mechanical, electrical, plumbing and fire protection trades in multi-story building construction," ASCE Construction Congress Proceedings, Managing Engineered Construction in Expanding Global Markets, pp. p 102, 1997.

[57] D. R. Riley and V. E. Sanvido, "Patterns of construction-space use in multistory buildings," Journal of Construction Engineering and Management, vol. 121, pp. 464, 1995.

[58] R. A. Rivas, J. D. Borcherding, V. González, and L. F. Alarcón, "Analysis of Factors Influencing Productivity Using Craftsmen Questionnaires: Case Study in a Chilean Construction Company," Journal of Construction Engineering \& Management, vol. 137, pp. $312,2011$.

[59] Y. Rosenfeld, "Root-Cause Analysis of Construction-Cost Overruns," Journal of Construction Engineering and Management, vol. 140, pp. 04013039, 2014.

[60] W. Schwartzkopf, Calculating Construction Damages, 2nd ed. New York, NY: Aspen Publishing, Inc., 2001.

[61] L. Song and S. M. AbouRizk, "Quantifying Engineering Project Scope for Productivity Modeling," Journal of Construction Engineering \& Management, vol. 131, pp. 360, 2005.

[62] Taylor, T.R.; Uddin, M.; Goodrum, P. M.;McCoy, A.;Shan, Y. W., "Change Orders and Lessons Learned: Knowledge from Statistical Analyses of Engineering Change Orders on Kentucky Highway Projects," Journal of Construction Engineering and Management-Asce, vol. 138, pp. 1360, 2012

[63] H. R. Thomas, "Effects of scheduled overtime on labor productivity," Journal of Construction Engineering and Management, vol. v 118, pp. p 60, 1992.

[64] H. R. Thomas and K. A. Raynar, "Scheduled overtime and labor productivity: Quantitative analysis.," Journal of Construction Engineering \& Management, vol. Vol. 123, pp. p181, 1997.

[65] H. R. Thomas and G. R. Smith, "Loss of Construction Labor Productivity Due to Inefficiencies and Disruptions: The Weight of Expert Opinion.," The Pennsylvania Transportation Institute 1990b.

[66] US-Army-Corps-of-Engineers, " Effect of Cold Weather on Productivity," US Army Cold Rehions Research and Engineering Laboratory, Hanover, New Hamshire 1986.

[67] US-Army-Corps-of-Engineers, "Modification Impact Evaluation Guide," Washington, D.C. 1979. 


\section{Proceedings of PICMET '16: Technology Management for Social Innovation}

[68] G. H. Williams and T. A. Anderson, "Impacts to Labor Productivity in Steel Framing and the Installation and Finishing of Gypsum Wallboard," Northwest Wall \& Ceiling Bureau, 2009.
[69] J. G. Zack Jr, "Practical Problems with Pricing Delay Using Eichleay," Cost Engineering, 2011. 